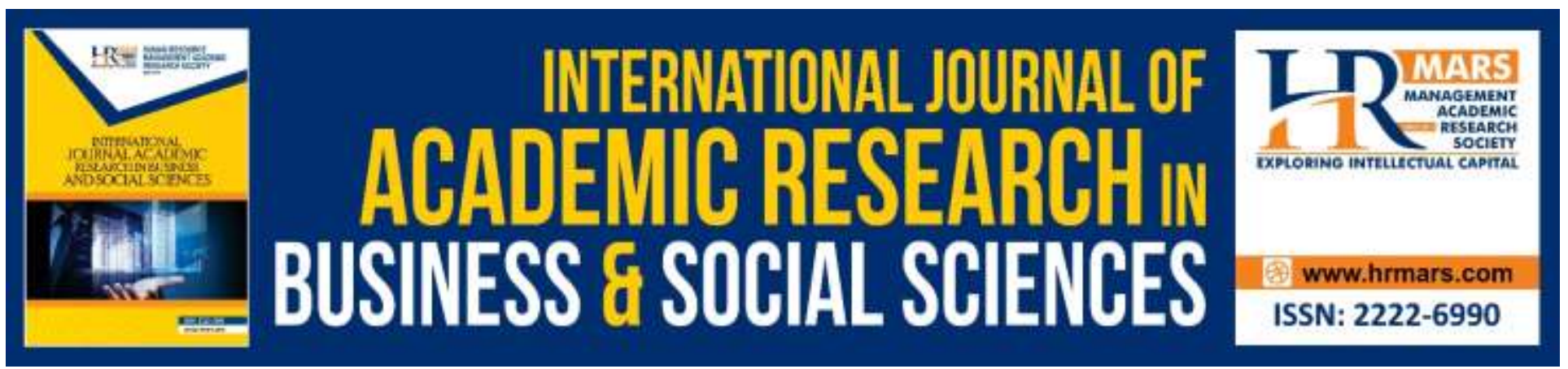

\title{
Media Literacy Dimension in Reinforcing Political Participation Integrity Among Young People in Social Media
}

Siti Nurshahidah Sah Allam, Mohd Sufiean Hassan, Abdul Mutalib Mohamed Azim, Anisafina Maidin, Siti Najah Raihan Sakrani

To Link this Article: http://dx.doi.org/10.6007/IJARBSS/v10-i3/7053

DOI:10.6007/IJARBSS/v10-i3/7053

Received: 02 February 2020, Revised: 22 February 2020, Accepted: 12 March 2020

Published Online: 29 March 2020

In-Text Citation: (Allam et al., 2020)

To Cite this Article: Allam, S. N. S., Hassan, M. S., Azim, A. M. M., Maidin, A., \& Sakrani, S. N. R. (2020). Media Literacy Dimension in Reinforcing Political Participation Integrity Among Young People in Social Media. International Journal of Academic Research in Business and Social Sciences, 10(3), 309-329.

Copyright: (C) 2020 The Author(s)

Published by Human Resource Management Academic Research Society (www.hrmars.com)

This article is published under the Creative Commons Attribution (CC BY 4.0) license. Anyone may reproduce, distribute, translate and create derivative works of this article (for both commercial and non-commercial purposes), subject to full attribution to the original publication and authors. The full terms of this license may be seen at: http://creativecommons.org/licences/by/4.0/legalcode

Vol. 10, No. 3, 2020, Pg. 309 - 329

Full Terms \& Conditions of access and use can be found at http://hrmars.com/index.php/pages/detail/publication-ethics 


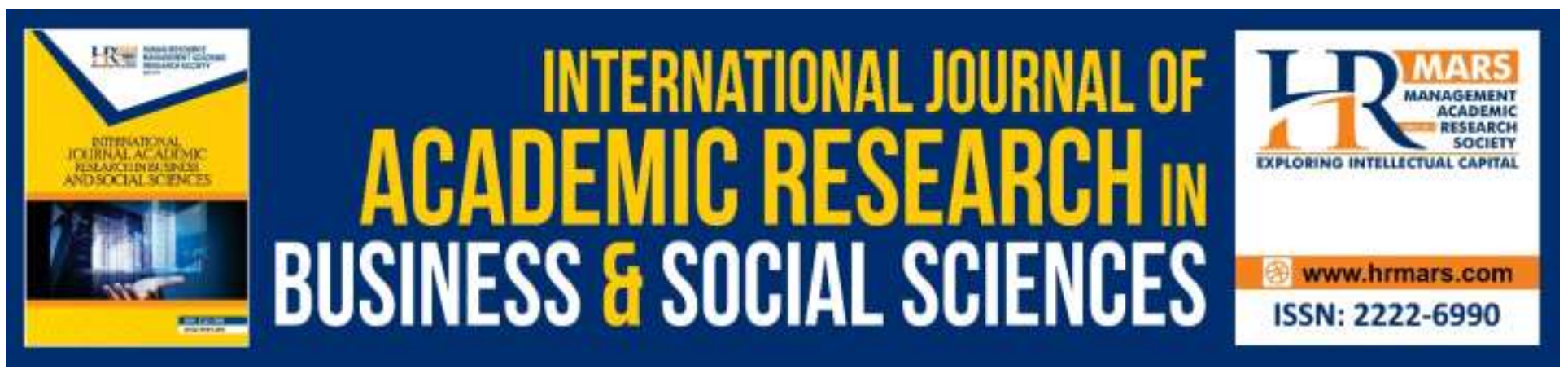

\title{
Media Literacy Dimension in Reinforcing Political Participation Integrity Among Young People in Social Media
}

\author{
Siti Nurshahidah Sah Allam \\ Universiti Teknologi MARA (UiTM), Melaka Branch, Malaysia \\ Mohd Sufiean Hassan, Abdul Mutalib Mohamed Azim \\ Kolej Universiti Islam Melaka (KUIM), Malaysia \\ Anisafina Maidin, Siti Najah Raihan Sakrani \\ Universiti Teknologi MARA (UiTM), Melaka Branch, Malaysia
}

\begin{abstract}
Innovation of technology in communication, especially social media offer an interactive platform for young people to participate in political activities. By using social media, lack of media literacy competency reported has a significant influence on low integrity conduct such as flashing provocation, joining the street demonstration, spreading fake news, defamation and slanders intentionally to create damage on certain political parties. This scenario significantly leads to high political cynicism that affected political participation integrity level among young people in social media. Since, low political participation integrity source of unhealthy democracy, this study aims to examine the effect of media literacy dimensions such as access, evaluation and act toward political participation integrity among young people in social media. A survey was used for data gathering among 388 Higher Education Institution students in Melaka. The data analyzed descriptively and inferentially using SPSS and SEM AMOS to provide an empirical understanding of news media literacy contribution towards political participation integrity. This study presents the significant effect of media literacy from dimensions of access, analysis and evaluation and acts towards political participation integrity. Surprisingly, educated yang people claimed from the previous study has little interest to politically engage in social media, basically participate in political activities such as neutralising negative comment in social media posted by the online community, reporting misconduct in social media to the authorized body and updating political information on certain issues using personal social media account.
\end{abstract}

Keywords: Media Literacy, Access, Analysis and Evaluation, Act, Political Participation, Integrity. 
INTERNATIONAL JOURNAL OF ACADEMIC RESEARCH IN BUSINESS AND SOCIAL SCIENCES

Vol. 10, No. 3, March, 2020, E-ISSN: 2222-6990 @ 2020 HRMARS

\section{Introduction}

The innovation of technology in communication, especially social media offers an interactive platform for young people to participate in political activities (Himelboim et al., 2012). By using social media, lack of new media literacy competency reported has significant influence to low integrity political activities such as making humour on political issues to create provocation (Kuipers, 2011), joining street demonstration (Al-Kandari \& Hasanen, 2012), spreading fake news), defamation and slanders (Cohen et al., 1988) with intentionally to create damage on certain political party.

Realizing young people are exposed to media impact (Kelly \& Payton, 2019), media literacy derived into age by providing an ethical guideline of media use (Aufderheide, 1992) and reinforcing political participation integrity among young people in social media (Sufiean et al., 2020). By having media literacy competency, young people predicted to be more critical in choosing a credible platform to get access into political information (Silverstone, 2004) and became critical thinker (Hobbs \& Frost, 2003) to produce new perspective of knowledge (Ashley et al., 2010).

Study on media literacy and political participation contribute new direction on defining access (Ashley \& Maksl, 2017; Calabrese, 2008). Early notions of access refer to accessibility of media to the community to spread information (Aufderheide, 1992) and updating operation definition in the 20th century (Jenkins, 2007) offers access measure to the extent of media platform accessible in the community (Ojebuyi \& Salawu, 2015) using the accessible ICT tools, applications and related software (Buckingham, 2005) to search credible information through reliable media.

Political scientists and media scholars reported that access to credible media (Alvídrez \& Franco-Rodríguez, 2016), develop the positive direction of political knowledge (O'Neill, 2010) and lead them to act in political activities with high integrity level. Another reason, access to media and able to analyse critically media content significantly influence civic engagement (Martens \& Hobbs, 2015) that influence young people quality life (Rebecca \& Matthew, 2008), develop social norms and reinforce political trust (Zhang \& Chia, 2006). Correspondingly, media literacy education reported can promote young people to act in political civic engagement (Martens \& Hobbs, 2015), reduce political apathy and cynicism (Vesnic-Alujevic, 2012) that strengthen political integrity among young people in social media.

The objective of this study; 1 ) to measure the effect of media literacy contribution from access dimension toward political participation integrity among young people in social media, 2) to analyse the effect of media literacy contribution from evaluate dimension toward political participation integrity among young people in social media and 3) to measure the effect of media literacy contribution from act dimension toward political participation integrity among young people in social media.

\section{Media Literacy Perspective}

Before printing world invented, oral culture transmitted information through speech rather than writing form which information dissemination highly depending on the expert. The early idea of literacy definition refers to an ability to read and write information in a variety of medium while growth in communication and media. Literacy is intensely important for the circulation of political interest. During the French revolution, the availability of printed media such as political newsletter and broadsheets was vital to the emergence of political empowerment, especially among young 
INTERNATIONAL JOURNAL OF ACADEMIC RESEARCH IN BUSINESS AND SOCIAL SCIENCES Vol. 10, No. 3, March, 2020, E-ISSN: 2222-6990 @ 2020 HRMARS

people. Changes of technology in producing documented media such as book significantly influence political involvement in society.

The invention of moveable metal the printing machine by Johannes Gutenberg allowed information documented known as a book. Numbers of a book published such as Public Opinion by Walter Lippmann (1920) and The Public and its Problems by John Dewey (1927) open new medium for audience gained new knowledge, especially to gratify their political interest. People used information gained in political debate that practices political efficacy. However, a lack of media literacy competency causes low integrity political participation. As a result, a number of media scholars believe that media literacy competency is a fundamental skill needed despite healthy democracy and high integrity political involvement.

Little apprehension study by political and media scientist on media literacy contribution towards political participation among young people. Moreover, media literacy influence vastly focus in education area where a study conducted to measure the effectiveness of media literacy curriculum in particular students group (Jolls, 2003; Cheung \& Xu, 2016), reduce stereotype between race and ethnicity (Scharrer \& Ramasubramanian, 2015), preparing communities to face ICT challenges (Marsh, 2008; Cakmak \& Izzet, 2015; Arsenijević \& Andevski, 2016), reducing digital divide (Radovanović et al., 2015) and strengthening awareness in the community (O'Dea, 2005; Austin et al., 2012; Hindmarsh et al., 2015). Many media scholars reported that there is a potential contribution by integrating media literacy with political participation dimensions (Calabrese, 2008; Kahne \& Lee, 2012; Mohd Sufiean et al., 2020).

According to Aufderheide (1993), media literacy competency develop a critical and ethical active audience. Employing the skill of access, analyse, evaluate and communicate information in a multiplatform, media users are able to make rational decisions (Mihailidis \& Thevenin, 2013) in choosing a credible platform (Johnson \& Kaye, 1998 \& Ghaddar et al., 2012) to search information through media. To measure media literacy skills social sciences scholars, believe that media users must be able to reproduce media content to develop new and share unique perspectives on selected issues with a new approach (Renee Hobbs \& Frost, 2003; Mcdougall et al., 2015).

In addition, the new media landscape offer multimedia platform conveys the user's idea in an interactive format. Critically using media information and analysing the messages to create one's own content. This ability developed users become critical thinker, creative content creator (Mohd Sufiean et al., 2019) and act as a high integrity change agent in society. Why moral, ethical or integrity conduct? Using social media as a communication platform exposed user to low integrity behaviour especially, involving political activities such as flashing provocation, joining the street demonstration, spreading fake news, defamation and slanders with intentionally to create damage on certain political party.

Media Literacy significantly influences the high level of political participation integrity among young people through media access, evaluate media content and act as an integrity change agent. According to Mcdougall et al., (2015), young people political involvement such as voting, attending town meeting, liking-sharing media content ethically guided by media literacy competency directly empower civic participation (Mihailidis \& Thevenin, 2013) to enhance integrity values among young generation known as a competent citizen (Meyers et al., 2013). Ability to make a rational decision of using credible media platform, critically evaluate media content develop high integrity of young people and political scientist mention as an element of a competent citizen. High involvement in 
INTERNATIONAL JOURNAL OF ACADEMIC RESEARCH IN BUSINESS AND SOCIAL SCIENCES Vol. 10, No. 3, March, 2020, E-ISSN: 2222-6990 @ 2020 HRMARS

political activities embedded with integrity values, basically shapes ethical active audience of media users as preparation for new generations in civic engagement. This study believes that engaging political activities with media literacy competency develop high political participation integrity among young people.

\section{How New Media Literacy Reinforce Political Participation Integrity}

The early perspective of media literacy is to study the ability to access, analyse, evaluate and communicate messages in a wide variety of forms (Aufderheide, 1993). The early notion to measure media literacy contribution is to highlight the skills of seeking media access (Shim et al., 2014), analysing and evaluating information sources (Renée Hobbs, 1998) in the media than creating media content that makes use of linguistic, multimedia elements such as video, audio (Livingstone, 2004), animation (Marsh, 2008) and hyperlink (Protopsaltis \& Bouki, 2009). The great idea of media literacy competency is to produce active users who not only be able to read the information but reproduce and create a new one (Mihailidis \& Thevenin, 2013) by giving society new perspective on pertaining issues (Blank, 2013). This idea supported and enhanced by Renee Hobbs \& Frost (2003), in learning to critically read media content, young people also develop the abilities to gather truthful, relevant and credible sources.

However, producing media content without media literacy competency reported by social scientists has a significant influence on low integrity political activities such as flashing provocation, joining the street demonstration, spreading fake news, defamation and slanders with intentionally to create damage on certain political party. This scenario significantly leads to high political cynicism that affected political participation integrity value among young people in social media. Subsequently, low political participation integrity among young people especially from the use of social media reported as sources of an unhealthy democracy. Apart from that, the involvement of young people in low integrity political activity linked to exposing themselves into criminal actions that impose legal action.

Here, revolving point of media literacy contribution towards political participation integrity suggested by having high-level of media literacy competency users become critical thinker (Potter, 2013), creative content creator (Livingstone, 2004) and change agent to serve the society (Santos et al., 2013). Furthermore, media literacy reported highly influence political participation (Calabrese, 2001; Kahne \& Lee, 2012; Kellner \& Share, 2006; Livingstone, 2003; Ojebuyi \& Salawu, 2015) and civic engagement (Martens \& Hobbs, 2015; Mcdougall et al., 2015; Mihailidis \& Thevenin, 2013). Civic engagement supported morals, values (Cemlyn \& Nye, 2012) and integrity conduct (Mohd Sufiean et al., 2020) among young people in social media. Following discussion emphasis the direction on media literacy reinforcing political participation integrity among young people that little concern by political scientist, especially from the dimensions of access, analysis and evaluate and act.

\section{Access Competency}

Access competency is a vital skill needed before young people be able to evaluate media content and act to participate with high integrity. Study on media literacy and political participation contribute new direction on defining access (Ashley \& Maksl, 2017; Calabrese, 2008). Early notions of access refer to accessibility of media to the community to spread information (Aufderheide, 1992) and updating operation definition in the 20th century (Jenkins, 2007) offers access measure to the 
INTERNATIONAL JOURNAL OF ACADEMIC RESEARCH IN BUSINESS AND SOCIAL SCIENCES Vol. 10, No. 3, March, 2020, E-ISSN: 2222-6990 @ 2020 HRMARS

extent of media platform accessible in the community (Ojebuyi \& Salawu, 2015) using the accessible ICT tools, applications and related software (Buckingham, 2005), level of motivations that lead interest to access media to search information (Kim \& Johnson, 2012) and by attending computer class, assisted by family and friends young people access to the media platform (Brandtweiner et al., 2010).

However, according to Aufderheide (1992), the access dimension definition could be expressed in many different ways. As for this study, access measure as the ability to find and share information with the public using the tools provided (Hobbs 2010). This includes updating personal profiles (Paulussen et al., 2010), sending and sharing information with other social media users (Maamari \& Zein, 2014). Correspondingly, access measure on individual skill to access multiplatform of media such as television, radio (Ojebuyi \& Salawu, 2015), internet (Bober et al., 2010), social media (Loader et al., 2014) and smartphone (Koo et al., 2014) significantly to get access political updates.

The idea of access dimension correlatively contribute towards political participation integrity among young people, high level of access to media and information, develop high political interest and political knowledge. According to Salman \& Hasim (2011) who study on access to online newspaper and general election reported that online media offer an interactive platform to society (Sufiean et al., 2019) where all citizens are guaranteed access, with the innovation of the Internet, anyone with a computer and Internet connection can easily search political information-driven by their political interest (Bakker \& Vreese, 2011).

This idea supported by Kim \& Johnson, (2012) who examined the motivations for why politically interested Internet users in the United States access political blogs and they found that blog users with higher levels of political participation and political inclination are attracted to political blogs to freely express their political judgement. Feature of blogs that offer the interactive platform, easy to communicate with the same interest and the potential of Weblogs as an interactive political discursive space make this media is accessible to the young people to get involved in online political activities.

However, according to Casero-Ripollés (2017), access to social media do not promise young people political engagement. Social media enhance young people skills to produce media content and information. However, not everybody has the same access to these benefits. This causes the emergence of a digital divide and the appearance of vulnerable sectors such as education level and frequency of digital network use. Apart from the education level and frequency of Internet use, news media content significantly contributes to lower political engagement among young people. According to Ojebuyi \& Salawu (2015), media offer information superhighway features but negative contents lead to political apathy. Family as socialization agents suggested driving young people political inclination towards integrity engagement through family discussion on current issues which develop young generation political knowledge.

In shaping political interest through political knowledge (Bakker \& Vreese, 2011), political scientist and media scholars believe that high media literacy rate contributes to high access information sources and high searching quality information (Pinkleton \& Austin, 2002). Reinforced by Bektas (2009), young people develop political inclination and political knowledge guided with high media literacy competency consistently enhance political participation integrity. This idea strengthening the notion of access to media for political information open to phenomena of information overload and media literacy competency significant subject for eliminating the harmful 
INTERNATIONAL JOURNAL OF ACADEMIC RESEARCH IN BUSINESS AND SOCIAL SCIENCES

Vol. 10, No. 3, March, 2020, E-ISSN: 2222-6990 @ 2020 HRMARS

effects of media access to reinforce political participation integrity among young people in social media.

$\mathrm{H} 1$ : There is an effect between access competency and political participation integrity among young people.

\section{Analysis and Evaluate Competency}

According to Hobbs (2010) analysis and evaluate competency refer to the mentally critical user; practice message composition and creativity; the ability to engage in ethics. When someone has media and digital literacy they will recognize the rights of others, their corporate, cultural and political agendas and exercise their right to speak based on integrity (Aufderheide 1993; Hobbs 2010).

The dimension of analysis and evaluate is considered an important medium of media literacy because, through media other than consumers, young people can act as producers of media content especially on social media. As such, many researchers in the fields of psychology, sociology, liberal media and socio-politics argue that the main goal of media literacy is to measure media use and the ability to analyze information in the media (Eristi \& Erdem, 2017). After accessing media content, a set of competencies such as analysis and evaluation is required. These competencies include the ability to analyze information sources and evaluate information sources from multiple sources (Lewis \& Jhally, 1998).

This analysis and evaluate also refers to the ability to understand information and critical thinking on information sources as well as the ability to compare information from different sources (Mohd Sufiean et. al). Besides, this aspect of analysis and evaluate measures the ability of young people to seek political information and to ensure that it has integrity that is authentic, accurate and ethical and moral (Hobbs, 2010).

Aspects of analysis and evaluate become more important to young people as technology adoption is faster than the adults and the interest in exploring technology applications directly improves access to information and thus leads to the aspects of analysis and resource evaluation (Lee 2005). In addition to the age factor, young people's education level is an indicator of their ability to analyze and evaluate sources of information to obtain accurate and valid information.

This idea was supported by Arsenijević, \& Andevski (2016) who conducted media literacy studies on the academic community in Serbia found that the level education in the field of education plays a major role in the field of information analysis and evaluate, where the technical-technology field has more analytical and higher information rating rather than social science. However, science social fields also contribute to the aspects of analysis and evaluate, in which the cognitive and psychomotor skills implemented in the syllabus directly generate critical thinking (Persson 2013).

The value of integrity is achieved through the comparative quality of political information (Wolfsfeld et al., 2015), where political information positively impacting civic activity in society (Trenz, 2014), strengthens the practice of national democracy (Chang, 2017) and belief in the political system (Kee, 2009), where this value of trust refers to (1) the integrity and efficiency of the leadership system, (2) the efficiency and moral value of coping with political pressures, and (3) prioritizing responsive actions to the people (Carlin, 2014).

However, previous studies also reported that political information especially news on social media had higher levels of provocative political information rather than conventional media such as 
INTERNATIONAL JOURNAL OF ACADEMIC RESEARCH IN BUSINESS AND SOCIAL SCIENCES Vol. 10, No. 3, March, 2020, E-ISSN: 2222-6990 @ 2020 HRMARS

Television, Radio and Newspapers (Sufiean et al., 2019) because political information on social media was not edited as a public reading, so it contained provocative information, slander and political sensation issues that are not reported in conventional media (Sufiean, Nurshahidah, Zuliani \& Hanapi, 2013).

$\mathrm{H} 2$ : There is an effect between analysis and evaluate competency and political participation integrity among young people.

\section{Act Competency}

Media literacy has enabled people to use media to communicate information, share ideas and news from other perspectives. With social media literacy, people will be more aware of their actions whether they have a positive or negative impact. It will also enable them to better understand how to act and not be acted upon (Malik, 2008).

According to (Skoric et al., 2016), suggested that access to social media use generally significant with engagement and its three sub-categories, that is, social capital, civic engagement, and political participation. Compared to traditional media such as radio, television and newspaper, social media offers interactive tools (Sufiean et al., 2019) that allow young people engage with online political activities such as political conversation, political discussion, signing an online petition, sharing political information, liking political updates from politicians account or social media users. Social media use reported as significantly influence online political participation among young people due to multiplatform and reach a wide audience which they can gratify their interest with people in-group.

According to (Willnat et al., 2013) who employ qualitative method on young people in Malaysia reported that social media use was significantly influenced levels of political participation among young people. The use of media and exposure to political media platform such as blogs, videos, Web sites, and political commercial on smartphones, reported strong associations with political activism. Young people who have access to political activism group positively associated with low political integrity that prone to aggressive behaviour either offline or online engagement. Aggressive act such as joining provocation, street demonstration and protesting reported influence by access to social media (Al-Kandari \& Hasanen, 2012) due to ease of use for political expression.

Supported by Edgerly et al., (2016) who explores political expression on social media during the presidential campaign on viral content found that the more political expression being viral, the more news media coverage chances are given. As a result of the posting practices of individuals using their Facebook as a site for individual expression (Sebastian V. \& Arturo A., 2012). Furthermore, political expression among young people (Östman, 2012) through hate speeches regarding politics and religious beliefs on Twitter that contain controversial issues, provocative judgement or containing expressions of hatred reported positive correlation towards low political participation integrity (Syahputra, 2019).

Realizing society exposed to media impact (Kelly \& Payton, 2019), media literacy derived into age by providing an ethical guideline of media use (Aufderheide, 1992) and reinforcing political participation integrity among young people (Sufiean et al., 2020). By having media literacy competency, young people predicted to be more rational in choosing a credible platform to get access into political information (Silverstone, 2004) and being critical thinker (Hobbs \& Frost, 2003) they can 
INTERNATIONAL JOURNAL OF ACADEMIC RESEARCH IN BUSINESS AND SOCIAL SCIENCES

Vol. 10, No. 3, March, 2020, E-ISSN: 2222-6990 C 2020 HRMARS

produce new perspective of knowledge where they become ethical active media users (Ashley et al., 2010).

The previous study reported that access to credible media (Alvídrez \& Franco-Rodríguez, 2016), develop the positive direction of political knowledge (O'Neill, 2010) and lead them to act in political activities with high integrity level. Another reason, access to media and able to analyse critically media content significantly influence civic engagement (Martens \& Hobbs, 2015) that influence young people quality life (Rebecca \& Matthew, 2008), develop social norms and reinforce political trust (Zhang \& Chia, 2006). Correspondingly, media literacy education reported can promote young people to act in political civic engagement (Martens \& Hobbs, 2015), reduce political apathy and cynicism (Vesnic-Alujevic, 2012) that strengthen political integrity.

H3: There is an effect between act competency and political participation integrity among young people.

\section{Research Methodology}

The respondents of this study were 388 Higher Education Institutions (HEI) students comprising four universities in Melaka, Malaysia. Student selection was based on random sampling. Based on the number of respondents $(n=388$ ) with complete data in this study, the sample size is large enough for the use of Structural Equation Modelling (SEM) (Hair, Black, Babin \& Anderson, 2010). Pilot study conducted to test the reliability of the instrument to ensure the consistency of the questionnaire. Cronbach Alpha's reliability coefficient for all four variables, above 0.70 , shows a good internal consistency (Hair et al., 2010).

The adapted instrument was reviewed by an expert and a pilot test was conducted to determine the validity of the items. The aim of this study is to identify indicators of media literacy scale using Exploratory Factor Analysis and to identify a structural measurement model using Confirmatory Factor Analisis (CFA).

\section{Research Instrument}

The questionnaire consists of two parts used as the instrument of this study. Part A consists of general information on demographic variables such as gender, age, status, race, education and social media usage. Part B contains a media literacy scale adapted from Mustafa Koc and Esra Barut (2016). The scale to measure media literacy is a well-established scale that has proven its reliability because it is widely used in past studies. Reliability cronbach alpha for all five media literacy are between 0.89 0.92. The steady use of the scale actually helps in terms of the reliability of the scale in gaining information through the public (Babbie, 2013). This scale contains 20 items and is measured using a seven-level interval scale of $1=$ strongly disagree to $7=$ strongly agree. This measurement scale measures access, analysis and evaluate, and act. 
INTERNATIONAL JOURNAL OF ACADEMIC RESEARCH IN BUSINESS AND SOCIAL SCIENCES Vol. 10, No. 3, March, 2020, E-ISSN: 2222-6990 @ 2020 HRMARS

Table 1 : Dimension of Media Literacy and Cronbach Alpha

\begin{tabular}{|l|l|l|l|}
\hline $\begin{array}{l}\text { Dimension of } \\
\text { media literacy }\end{array}$ & Research Instruments & Operational Definition & $\begin{array}{l}\text { Cronbach } \\
\text { Alpha }\end{array}$ \\
\hline Access & $\begin{array}{l}\text { New Media Literacy Scale } \\
\text { (NMLS) Mustafa Koc and } \\
\text { Esra Barut (2016) }\end{array}$ & $\begin{array}{l}\text { Access refers to individuals } \\
\text { should have the skills to access } \\
\text { political information efficiently } \\
\text { on social media networks (sign } \\
\text { ups, logins and sent messages) } \\
\text { and using social media } \\
\text { (uploading and downloading } \\
\text { videos, editing photos, etc.). }\end{array}$ & .92 \\
\hline $\begin{array}{l}\text { Analysis and } \\
\text { Evaluate }\end{array}$ & $\begin{array}{l}\text { New Media Literacy Scale } \\
\text { (NMLS) Mustafa Koc and } \\
\text { Esra Barut (2016) }\end{array}$ & $\begin{array}{l}\text { Analysis and evaluate refers to } \\
\text { the ability to determine } \\
\text { whether the content of political } \\
\text { information on social media is } \\
\text { ethical, moral, integrity by } \\
\text { comparing political information } \\
\text { from one source to another on } \\
\text { social media. }\end{array}$ & .92 \\
\hline Act & $\begin{array}{l}\text { New Media Literacy Scale } \\
\text { (NMLS) Mustafa Koc and } \\
\text { Esra Barut (2016) }\end{array}$ & $\begin{array}{l}\text { Act refs to the activity of } \\
\text { uploading legitimate political } \\
\text { information / news / articles to } \\
\text { share with netizens. Provides } \\
\text { positive and unbiased feedback } \\
\text { on negative, immoral, ethical, } \\
\text { and politically incorrect entries / } \\
\text { comments on social media and } \\
\text { reports to social media for } \\
\text { misconduct. }\end{array}$ & \\
\hline & & .89 \\
\hline
\end{tabular}

\section{Data Analysis}

The data were analyzed by using descriptive statistic to describe the respondent profile of the study and exploratory factor analysis (EFA) with IBM SPSS 22.0 software. Analyzing EFA is an important foundation for strengthening the construction of constructs (Schumacker \& Lomax, 2010). The main use of EFA is to reduce the number of items and to detect the relationship structure between items that make up the construct dimension (Hair et al., 2010). In this study, principal component analysis with varimax rotation is used to determine the number of components.

AMOS 21.0 software was used to perform Confirmatory Factor Analysis (CFA). The CFA aims to determine the number of items included in the constructs in parallel with what is stated in theory (Byrne, 2010). The accuracy of the CFA model matching is determined by a combination of at least one Absolute Fit Indices and one Incremental Fit Indices (Hu \& Bentler 1999; Hair et al., 2010) and Parsimony Fit Indices (PFI) (Hair et al., 2010). The test on CFA is used to determine whether the tested 
INTERNATIONAL JOURNAL OF ACADEMIC RESEARCH IN BUSINESS AND SOCIAL SCIENCES

Vol. 10, No. 3, March, 2020, E-ISSN: 2222-6990 C 2020 HRMARS

model should be accepted or rejected. However, there is no specific rule that determines whether a compatibility index needs to be reported for a model (Hooper, Coughlan \& Mullen; 2008, Hair et al., 2010). The use of three or more compatibility indexes is sufficient to prove a model fit, without to report all existing fit indexes (Hair et al., 2010).

\section{Findings}

Exploratory Factor Analysis (EFA), Media Literacy

The Media Literacy Measurement Scale tested consists of three constructs: Access, Analysis and Evaluate and Act with and 20 items. Kaiser-Meyer Olkin Measure of Sampling Adequacy (KMO) value $=0.942$ is above the value of $>0.6$ to meet the exploratory factor analysis (Hair et al., 2010; Pallant, 2007). While the value of Bartlett's Test is significant $(p<.05)$. This shows that the items used in the Exploration Factor Analysis of this study have good inter-correlation strengths with each other. Table 2 shows the result of Construct matrix correlation.

Table 2 : Media Literacy Correlations Matriks

\begin{tabular}{|c|c|c|c|}
\hline \multicolumn{3}{|c|}{ Kaiser-Meyer-Olkin Measure of Sampling Adequacy. } & .942 \\
\hline \multirow[t]{3}{*}{$\begin{array}{l}\text { Bartlett's } \\
\text { Sphericity }\end{array}$} & Test of & Approx. Chi-Square & 9775.983 \\
\hline & & $\mathrm{df}$ & 528 \\
\hline & & sig. & .000 \\
\hline
\end{tabular}

According to Hair et al. (2010), items with low loading factor from 0.50 should be removed. In this study, all items accepted due to factor loading greater than 0.50, which are in between 0.523 to .978. To test convergent validity, researchers use Average Variance Extracted (AVE) and Construct Reliability (CR). According to Hair et al. (2010), the AVE value should be greater than 0.5 and CR is greater than 0.7. Based on AVE's decision for access, analysis and evaluate and act, these three constructs exceeded 0.5 . The reliability value of all four latent variables (constructs) ranges from 0.866 to 0.925 , greater than 0.70 , shows that Cronbach's alpha is in good condition. The discriminant validity is to measure one construct with another construct and should not have a high correlation. Byren (2010) suggests that the value of $r=0.90$ or more indicates that the variable has a high correlation. Since the correlation findings in Table 3 show values in between 0.785 to 0.831 , this means that there is no high correlation problem (multicollinearity).

Table 3: Average Variance Extracted, Constructs Reliability and Correlation

\begin{tabular}{|c|c|c|c|c|c|c|c|c|}
\hline $\begin{array}{l}\text { Latent Variable } \\
\text { (Constructs) }\end{array}$ & CR & AVE & A & Access & $\begin{array}{l}\text { Analysis } \\
\text { and } \\
\text { Evaluate }\end{array}$ & Create & Reflect & Act \\
\hline Access & 0.866 & 0.620 & 0.968 & 0.787 & & & & \\
\hline $\begin{array}{l}\text { Analysis and } \\
\text { Evaluate }\end{array}$ & 0.925 & 0.639 & 0.930 & 0.612 & 0.800 & & & \\
\hline Act & 0.899 & 0.690 & 0.975 & 0.285 & 0.529 & 0.725 & 0.886 & 0.831 \\
\hline
\end{tabular}

Note: $A V E=$ Average Variance Extracted, $C R=$ Contsruct Reliability, $\alpha=$ Cronbach Alpha 
INTERNATIONAL JOURNAL OF ACADEMIC RESEARCH IN BUSINESS AND SOCIAL SCIENCES Vol. 10, No. 3, March, 2020, E-ISSN: 2222-6990 @ 2020 HRMARS

Table 4 : Factor Loading Hypotheses to Constructs Indicators

\begin{tabular}{llll}
\hline \multicolumn{2}{c}{ Indication } & Construct & $\begin{array}{l}\text { Statistik } \\
\text { Loading }\end{array}$ \\
\hline Ak 1 & $\leftarrow$ & Access & $.906^{* * *}$ \\
Ak 2 & $\leftarrow$ & Access & $.961^{* * *}$ \\
Ak 3 & $\leftarrow$ & Access & $.947^{* * *}$ \\
Ak 4 & $\leftarrow$ & Access & $.873^{* * *}$ \\
Ak 5 & $\leftarrow$ & Access & $.535^{* * *}$ \\
Ak 6 & $\leftarrow$ & Access & $.824^{* * *}$ \\
Ak 7 & $\leftarrow$ & Access & $.562^{* * *}$ \\
AP1 & $\leftarrow$ & Analysis and Evaluate & $.929^{* * *}$ \\
AP 2 & $\leftarrow$ & Analysis and Evaluate & $.974^{* * *}$ \\
AP 3 & $\leftarrow$ & Analysis and Evaluate & $.963^{* * *}$ \\
AP 4 & $\leftarrow$ & Analysis and Evaluate & $.819^{* * *}$ \\
AP 5 & $\leftarrow$ & Analysis and Evaluate & $.862^{* * *}$ \\
AP 6 & $\leftarrow$ & Analysis and Evaluate & $.832^{* * *}$ \\
AP 7 & $\leftarrow$ & Analysis and Evaluate & $.821^{* * *}$ \\
TK 1 & $\leftarrow$ & Act & $.945^{* * *}$ \\
TK 2 & $\leftarrow$ & Act & $.978^{* * *}$ \\
TK 3 $\leftarrow$ & Act & $.898^{* * *}$ \\
TK 4 & $\leftarrow$ & Act & $.846^{* * *}$ \\
TK 5 & $\leftarrow$ & Act & $.941^{* * *}$ \\
TK 6 & $\leftarrow$ & Act & $.949^{* * *}$ \\
\hline
\end{tabular}

*** Standardized Regression Weights significant level at the .001 (2 tailed)

Based on Table 4, all loading factors are significant at the level of 0.001 and above 0.5 for all indicators. In addition, high standard regression values (0.523 to 0.978$)$ indicate that all measured indicators are significantly representing their latent variables - constructs.

\section{Confirmatory Factor Analysis (CFA) Media Literacy}

Model specifications include 20 items, seven items for access, seven items for analysis and evaluate and six items for act. However, this model should be modified in order to improve the fit of this model represents the sample data or real data better. Modifications are made by reference to the modification index. As a result, items AK1 (.46), AK4 (.38), AK7 (.48), TK5 (.42) and TK6 (.41) in the model had to be removed due to low loading factors $<0.5$. Next, items with high Modification Indice (MI) and high correlation between the two items were also modified. According to Hair et al. (2014), if there is a high correlation between the two items, they can be combined to obtain a model fit. Whereas if the item is not theoretically supported, the model needs to be modified by removing either one items with lower factor loadings (Hair et al. 2014).

The measurement model in Table 5 shows a good data fit with eight indicators ( $\chi 2$, CMINDF, RMSEA, GFI, IFI, TLI, CFI and PGFI) as shown in Table 5. However, Marsh \& Hau (1996) Chi-square (X2) can be divided by degrees of freedom $(\mathrm{df}=100)$ to evaluate model fit compared to using $\chi 2$ (CMINDF). If the CMINDF statistics count is less than the value of 5 , the fit of the data for the validation factor 
INTERNATIONAL JOURNAL OF ACADEMIC RESEARCH IN BUSINESS AND SOCIAL SCIENCES

Vol. 10, No. 3, March, 2020, E-ISSN: 2222-6990 @ 2020 HRMARS

model is good (Marsh \& Hau, 1996). CMINDF for this measurement model is less than the value of 5 (CMINDF $=2.250$ ). This shows a fairly good CFA model. Furthermore, the RMSEA value is 0.057 which is lower than .08 as suggested by Kline (2010). The index coefficients in Table 5 are all greater than 0.90 show a good model fit (Byrne, 2010), and the PGFI value is greater than 0.5 (.700) which also shows a good model fit with data (Hair, et al., 2010). Fifteen (15) items have been combined due to the high index value of the modification (M.I). Figure 1 shows the CFA Model for this study.

Table 5: Confirmatory Factor Analysis (CFA)

\begin{tabular}{lllllllll}
\hline Description & $\boldsymbol{\chi}^{2}$ & CMINDF & RMSEA & GFI & IFI & TLI & CFI & PGFI \\
\hline CFA Model & 573.785 & 2.250 & 0.057 & 0.892 & 0.956 & 0.948 & 0.956 & .700 \\
\hline
\end{tabular}

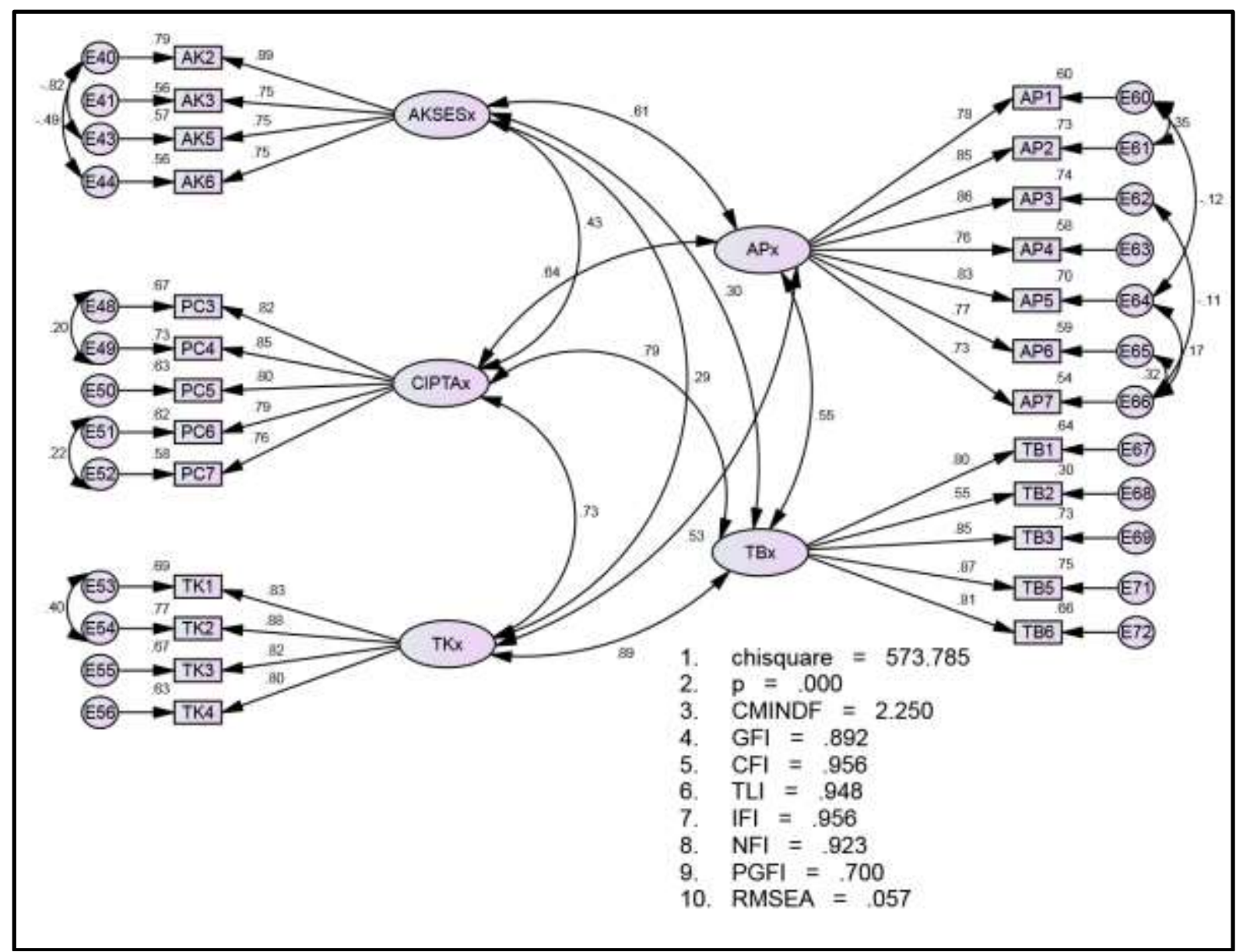

Figure 1: $\quad$ Confirmatory Factor Analysis Model of Media Literacy

Table 6: Structural Equations Modelling (SEM) Analysis

\begin{tabular}{lllllllll}
\hline Description & $\chi^{2}$ & CMINDF & RMSEA & GFI & IFI & TLI & CFI & PGFI \\
\hline SEM Model & 235.709 & 1.948 & 0.049 & .935 & .976 & .969 & .976 & .661 \\
\hline
\end{tabular}




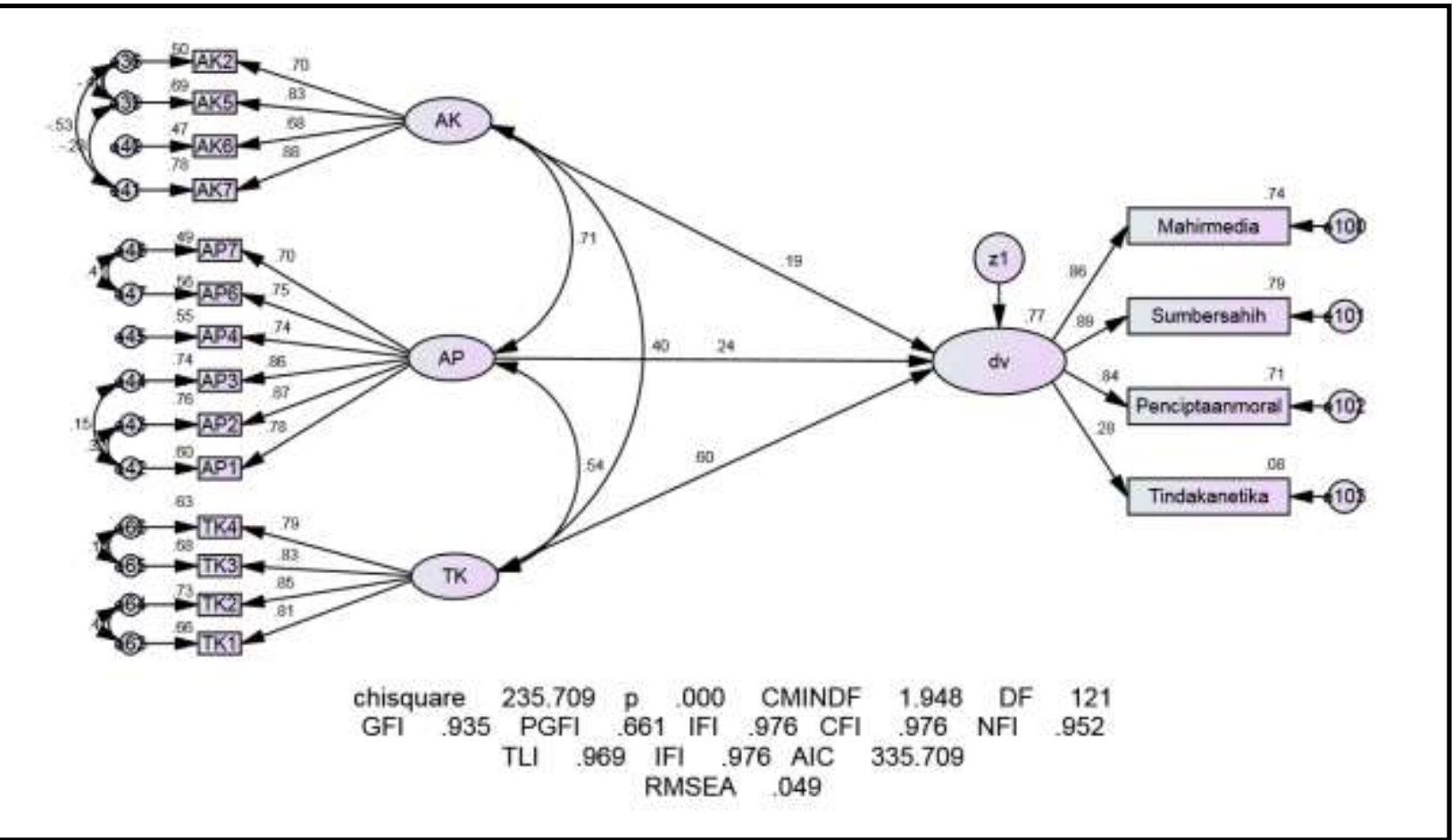

Figure 2: Structural Equation Modelling of Political Participation Integrity

Table 7: $\quad$ Standardized Regression Weight

\begin{tabular}{|c|c|c|c|c|c|c|c|c|}
\hline \multicolumn{9}{|c|}{ Standardized Regression Weight / Path coefficient } \\
\hline & & & & & Standard $(\beta)$ & S.E. & C.R. & $P$ \\
\hline $\begin{array}{l}\text { Political } \\
\text { Integrity }\end{array}$ & Participation & $<--$ & Access & & .19 & .427 & 3.531 & $* * *$ \\
\hline $\begin{array}{l}\text { Political } \\
\text { Integrity }\end{array}$ & Participation & $<---$ & $\begin{array}{l}\text { Analysis } \\
\text { Evaluate }\end{array}$ & & .24 & .505 & 3.916 & $* * *$ \\
\hline $\begin{array}{l}\text { Political } \\
\text { Integrity }\end{array}$ & Participation & $<---$ & Act & & .60 & .383 & 11.428 & $* * *$ \\
\hline
\end{tabular}


INTERNATIONAL JOURNAL OF ACADEMIC RESEARCH IN BUSINESS AND SOCIAL SCIENCES Vol. 10, No. 3, March, 2020, E-ISSN: 2222-6990 @ 2020 HRMARS

\section{Discussion}

Findings show that multi-dimensional models of media literacy scales have achieved a good model fit and achieve convergence validity based on significant relationship variables. The confirmatory factor analysis model (CFA) with construct validity also illustrates that the constructs of access, analysis and evaluate and act in the essential competencies of media literacy have been valid tested to represent their respective constructs. However, this scale is limited to measuring young people who actively use social media. The results of the three predictors of access, analysis and evaluate and act found all the predictor variables accepted. Table 7 also shown that all variable tested significantly has an effect on the political participation integrity among young people. Act predictors (path coefficient = $0.60, p<0.05$ ) were higher predictors than analysis and evaluate (path coefficient $=0.24, p<0.05$ ) and access (path coefficient $=0.19, p<0.05$ ). This means that access is not a major contributor to the political participation integrity among young people in social media as opposed to action and analysis and evaluation. Although access to social media is not a regular activity, it is significant to mention that the actions and evaluation of social media use can have an impact on the integrity of political participation. Overall, these three factors contributed 0.77 or 77 per cent of the variance to the political participation integrity of young people in social media.

\section{Conclusion}

Media literacy competency is vital for media use among young people who engage in political activities with a high level of integrity. The objective of this study is to measure the effect of media literacy contribution from access, evaluate and act dimension toward political participation integrity among young people in social media. Surprisingly, educated yang people claimed from the previous study has little interest to politically engage in social media, basically participate in political activities such as neutralising negative comment in social media posted by the online community, reporting misconduct in social media to the authorized body and updating political information on certain issues using personal social media account.

The findings of this study highly contributed to Malaysia Education Policy and Malaysian Communications and Multimedia Commission (MCMC) for media literacy education awareness among young people in using social media. Furthermore, this study highly contributes to the body of knowledge by integrating media literacy perspective and political participation integrity among young people in social media that little attention given by social scientist and media scholar. Apart from that, this study opens a new angel of knowledge by analysing integrity conduct among young people in political participation. The future researcher recommended exploring the contribution of social control perspective towards political participation integrity among young people in social media. Besides, media literacy dimensions, social control reported significantly develop integrity conduct in the community.

\section{Corresponding Author}

Siti Nurshahidah Sah Allam is a senior lecturer at di Faculty Communication and Media Studies, Universiti Teknologi MARA (UiTM), Melaka. Email: shahidah321@uitm.edu.my 
INTERNATIONAL JOURNAL OF ACADEMIC RESEARCH IN BUSINESS AND SOCIAL SCIENCES

Vol. 10, No. 3, March, 2020, E-ISSN: 2222-6990 @ 2020 HRMARS

\section{References}

Al-Kandari, A., \& Hasanen, M. (2012). The Impact Of The Internet On Political Attitudes In Kuwait And Egypt. Telematics And Informatics, 29(3), 245-253.

Alvídrez, S., \& Franco-Rodríguez, O. (2016). Powerful Communication Style On Twitter: Effects On Credibility And Civic Participation/Estilo Comunicativo Súbito En Twitter: Efectos Sobre La Credibilidad Y La Partici- Pación Cívica. Comunicar, 24(47), 89-97.

Arsenijević, J., \& Andevski, M. (2016). New Media Literacy within the Context of Socio-Demographic Characteristics. Procedia Technology, 22, 1142-1151.

Ashley, S., \& Maksl, A. (2017). News Media Literacy and Political Engagement: What's the Connection? Journal of Media Literacy Education, 9(1), 79-98.

Ashley, S., Poepsel, M., \& Willis, E. (2010). Media Literacy and News Credibility: Does Knowledge of Media Ownership Increase Skepticism in News Consumers? Journal of Media Literacy Education, 2, 37-46.

Aufderheide, P. (1992). A Report of The National Leadership Conference on Media Literacy.

Aufderheide, P. (1993). Media Literacy: A Report of the National Leadership Conference on Media Literacy. In Media literacy in the Information age current perspectives, 6(2).

Austin, E. W., Pinkleton, B. E., Austin, B. W., \& Van De Vord, R. (2012). The relationships of information efficacy and media literacy skills to knowledge and self-efficacy for health-related decision making. Journal of American College Health, 60(8), 548-554.

Babbie, E. (2013). The Practice of Social Research (13th ed.). Wadsworth, Cengage Learning.

Bakker, T. P., \& Vreese, C. H. (2011). Good News for the Future? Young People, Internet Use, and Political Participation. Communication Research, 38(4), 451-470.

Bektas, M. Ç. (2009). Media Literacy Courses In Faculties Of Communication in TRNC. Procedia Social and Behavioral Sciences, 1, 446-449.

Blank, G. (2013). Who Creates Content?: Stratification And Content Creation On The Internet. Information Communication and Society, 16(4), 590-612.

Bober, M., Livingstone, S., \& Helsper, E. (2010). Internet Literacy Among Children And Young People: Findings From The UK Children Go Online Project. LSE Research Online, 25.

Brandtweiner, R., Donat, E., \& Kerschbaum, J. (2010). How To Become A Sophisticated User: A TwoDimensional Approach to e-literacy. New Media \& Society, 12(5), 813-833.

Buckingham, D. (2005). The Media Literacy of Children and Young People. London: Ofcom.

Cakmak, E., \& Izzet, A. (2015). Debates about the Future of Media Literacy in Turkey. Journal of Media Literacy Education, 7(3), 1-12.

Calabrese, A. (2001). Political Significance of Media Literacy.pdf. VUB Brussel University Press. www.vubpress.be

Calabrese, A. (2008). The Political Significance of Media Literacy. UN-Alliance of Civilizations Media Literacy Education Clearinghouse

Casero-Ripollés, A. (2017). Producing Political Content For Web 2.0: Empowering Citizens And Vulnerable Populations. El Profesional de La Información, 26(1), 13.

Cemlyn, S. J., \& Nye, M. (2012). Asylum Seeker Young People: Social Work Value Conflicts In Negotiating Age Assessment In The UK. International Social Work, 55(5), 675-688.

Cheung, C. K., \& Xu, W. (2016). Promoting Media Literacy Education In China: A Case Study Of A Primary School. In International Journal of Adolescence and Youth. 6 (2), 215-217 
INTERNATIONAL JOURNAL OF ACADEMIC RESEARCH IN BUSINESS AND SOCIAL SCIENCES

Vol. 10, No. 3, March, 2020, E-ISSN: 2222-6990 @ 2020 HRMARS

Cohen, J., Mutz, D., Price, V., \& Gunther, A. (1988). Perceived Impact of Defamation. Public Opinion Quarterly, 52(2), 161-173.

Edgerly, S., Thorson, K., Bighash, L., \& Hannah, M. (2016). Posting about politics: Media as resources for political expression on Facebook. Journal of Information Technology and Politics, 13(2), 108125.

Ghaddar, S. F., Valerio, M. A., Garcia, C. M., \& Hansen, L. (2012). Adolescent Health Literacy: The Importance Of Credible Sources For Online Health Information. Journal of School Health, 82(1), 28-36.

Himelboim, I., Lariscy, R. W., Tinkham, S. F., \& Sweetser, K. D. (2012). Social Media And Online Political Communication: The Role Of Interpersonal Informational Trust And Openness. Journal of Broadcasting \& Electronic Media, 56(1), 92-115.

Hindmarsh, C. S., Jones, S. C., \& Kervin, L. (2015). Effectiveness Of Alcohol Media Literacy Programmes: A Systematic Literature Review. Health Education Research, 30(3), 449-465.

Hobbs, R., \& Frost, R. (2003). Measuring The Acquisition Of Media-Literacy Skills. Reading Research Quarterly, 38(3), 330-355.

Hobbs, Renée. (1998). The Seven Great Debates In The Media Literacy Movement. Journal of Communication, 48(1), 16-32.

Hobbs, Renee, \& Frost, R. (2003). Measuring The Acquisition pf Media Literacy Skills. Reading Research Quarterly. 38(3), 330-355.

Jenkins, H. (2007). Confronting The Challenges Of Participatory Culture: Media Education For The 21st Century (Part Two). Nordic Journal of Digital Literacy, 02.

Johnson, T. J., \& Kaye, B. K. (1998). Cruising Is Believing?: Comparing Internet And Traditional Sources On Media Credibility Measures. Journalism And Mass Communication Quaterly, 75(2), 325-340.

Jolls, E. T. T. (2003). Literacy fot the 21st Century: An Overview \& Orientation Guide to Media Literacy Education (Issue 2003).

Kahne, J., \& Lee, N. (2012). Digital Media Literacy Education and Online Civic and Political Participation College of Charleston. International Journal of Communication. 6(1):1-24

Kelly, J., \& Payton, E. (2019). A Content Analysis Of Local Media Framing Of Intimate Partner Violence. Violence and Gender.

Kim, D., \& Johnson, T. J. (2012). Political Blog Readers: Predictors Of Motivations For Accessing Political Blogs. Telematics And Informatics, 29(1), 99-109.

Koc, M., \& Barut, E. (2016). Development and validation of New Media Literacy Scale (NMLS) for university students. Computers in Human Behavior, 63(October), 834-843.

Koo, C., Chung, N., \& Kim, D. J. (2014). How Do Social Media Transform Politics? The Role Of A Podcast, "Naneun Ggomsuda" In South Korea. Information Development, 31(5), 1-14.

Kuipers, G. (2011). The Politics Of Humour In The Public Sphere: Cartoons, Power And Modernity In The First Transnational Humour Scandal. European Journal of Cultural Studies, 14(1), 63-80.

Livingstone, S. (2003). The Changing Nature and Uses of Media Literacy. Political Science, 32(4), 653677.

Livingstone, S. (2004). Media Literacy And The Challenge Of New Information And Communication Technologies. Communication Review, 7(1), 3-14.

Loader, B. D., Vromen, A., \& Xenos, M. A. (2014). The Networked Young Citizen: Social Media, Political Participation And Civic Engagement. Information Communication and Society. 17(2), 1-212. 
INTERNATIONAL JOURNAL OF ACADEMIC RESEARCH IN BUSINESS AND SOCIAL SCIENCES

Vol. 10, No. 3, March, 2020, E-ISSN: 2222-6990 @ 2020 HRMARS

Maamari, B. E., \& Zein, H. E. (2014). The Impact of Social Media on the Political Interests of the Youth in Lebanon at the Wake of the Arab Spring. Social Science Computer Review, 32(4), 496-505.

Malik, S. (2008). Media Literacy and its Importance. Islamabad: Society for Alternative Media and Research.

Marsh, J. (2008). Emergent Media Literacy : Digital Animation in Early Childhood Emergent Media Literacy : Digital Animation in Early Childhood. December 2014, 37-41.

Martens, H., \& Hobbs, R. (2015). How Media Literacy Supports Civic Engagement in a Digital Age. Atlantic Journal of Communication, 23(2), 120-137.

Mcdougall, J., Berger, R., Fraser, P., \& Zezulkova, M. (2015). Media Literacy, Education \& (Civic) Capability: A Transferable Methodology. Journal of Media Literacy Education, 7(1), 4-17.

Meyers, E. M., Erickson, I., \& Small, R. V. (2013). Digital literacy and informal learning environments: An introduction. Learning, Media and Technology, 38(4), 355-367.

Mihailidis, P., \& Thevenin, B. (2013). Media Literacy as a Core Competency for Engaged Citizenship in Participatory Democracy. American Behavioral Scientist, 57(11), 1611-1622.

Sufiean, M. H., Nurshahidah, S. A., Mutalib, A. M. A., Haizan, M., \& Afendi, M. D. (2020). Measuring the Integrity of Young People Political Participation: Psychometric Analysis of Media Literacy. International Journal of Academic Research in Business and Social Sciences, 10(2), 1-22.

Sufiean, M. H., Nurshahidah, S. A., Hanapi, M. K., Hilmi, M. B., \& Rauf, A. H. R. (2019). Perspektif Literasi Media Aspek Analisis Dan Penilaian : Amalan Integriti Penyertaan Politik Golongan Muda di Media Sosial. Jurnal Sains Sosial, 4(1), 20-32.

O'Dea, J. A. (2005). School Based Health Education Strategies For The Improvement Of Body Image And Prevention Of Eating Problems. Health Education, 105(1), 11-33.

O'Neill, B. (2010). The media's role in shaping Canadian civic and political engagement. Policy and Society, 29(June), 37-51.

Ojebuyi, B. R., \& Salawu, A. (2015). Media Literacy, Access and Political Participation among South African Black Youth: A Study of North-West University, Mafikeng Campus. Journal of Communication, 6(1), 207-218.

Östman, J. (2012). Information, expression, participation: How involvement in user- generated content relates to democratic engagement among young people. New Media and Society, 14(6), 1004-1021.

Paulussen, S., Courtois, C., Mechant, P., \& Verdegem, P. (2010). Adolescents ' New Media Literacy in Flanders ( Belgium ). 4, 361-374.

Pinkleton, B. E., \& Austin, E. W. (2002). Exploring Relationships Among Media Use Frequency, Perceived Media Importance, and Media Satisfaction in Political Disaffection and Efficac. Mass Communication and Society, 5(2), 207-228.

Potter, W. J. (2013). Review of Literature on Media Literacy. Sociology Compass, 6, 417-435.

Protopsaltis, A., \& Bouki, V. (2009). Gender Patterns in Hypertext Reading. 104-113.

Radovanović, D., Hogan, B., \& Lalić, D. (2015). Overcoming digital divides in higher education: Digital literacy beyond Facebook. New Media \& Society, 17(10), 1733-1749.

Rebecca, W.-S., \& Matthew, S. W. (2008). Political Participation and Quality of Life. In Inter-American Development Bank (Issue July).

Salman, A., \& Hasim, M. S. (2011). New Media and Democracy : The Changing Political Landscape in Malaysia. Akademika, 81(1), 15-21. 
INTERNATIONAL JOURNAL OF ACADEMIC RESEARCH IN BUSINESS AND SOCIAL SCIENCES

Vol. 10, No. 3, March, 2020, E-ISSN: 2222-6990 @ 2020 HRMARS

Santos, R., Azevedo, J., \& Pedro, L. (2013). Worldwide Commonalities and Challenges in Information Literacy Research and Practice. In Communications in Computer and Information Science (Vol. 397, Issue October).

Scharrer, E., \& Ramasubramanian, S. (2015). Intervening in the Media's Influence on Stereotypes of Race and Ethnicity: The Role of Media Literacy Education. Journal of Social Issues, 71(1), 171185.

Valenzuela, S., Arriagada, A. S. (2012). The Social Media Basis of Youth Protest Behavior : The Case of Chile. Journal of Communication, 1-16.

Shim, H., You, K. H., Lee, J. K., \& Go, E. (2014). Why Do People Access News With Mobile Devices? Exploring The Role Of Suitability Perception And Motives On Mobile News Use. Telematics and Informatics, 32(1), 108-117.

Silverstone, R. (2004). Regulation, Media Literacy and Media Civics. Media, Culture \& Society, 26(3), 440-449.

Skoric, M. M., Zhu, Q., Goh, D., \& Pang, N. (2016). Social Media And Citizen Engagement: A MetaAnalytic Review. New Media \& Society, 18(9), 1817-1839.

Syahputra, I. (2019). Expressions Of Hatred And The Formation Of Spiral Of Anxiety On Social Media In Indonesia. SEARCH (Malaysia), 11(1), 95-112.

Tucker, J. A., \& Guess, A. (2018). Social Media, Political Polarization, and Political Disinformation : A Review of the Scientific Literature. SSRN Electronic Journal. March, 1-95.

Vesnic-Alujevic, L. (2012). Political Participation and Web 2.0 in Europe: A Case Study of Facebook. Public Relations Review, 38(3), 466-470.

Willnat, L., Wong, W. J., Tamam, E., \& Aw, A. (2013). Online Media And Political Participation: The Case of Malaysia. Mass Communication and Society.

Zhang, W., \& Chia, S. C. (2006). The Effects of Mass Media Use and Social Capital on Civic and Political Participation. Communication Studies, 57(3), 277-297. 
INTERNATIONAL JOURNAL OF ACADEMIC RESEARCH IN BUSINESS AND SOCIAL SCIENCES Vol. 10, No. 3, March, 2020, E-ISSN: 2222-6990 (C) 2020 HRMARS

Appendix: Item Media Literacy

\section{Access}

No Item

Statisti

C

Loadin

g

1 I'm good in accessing social media networks (sign ups, logins and sent messages).

$.906 * *$

I'm good in using social media tools.

$.961^{* *}$

I'm good in using social media (uploading and downloading videos, editing $.947^{* *}$ pictures, etc).

4 I'm good in using search applications to find information on social media.

5 I am able to use various social media to find political information. communicating, finding friends, and playing online games.

7 I am able to identify my thoughts and views on political issues on social media.

\section{Analysis and Evaluate}

\begin{tabular}{clc}
\hline No & Item & $\begin{array}{c}\text { Statistic } \\
\text { Loading }\end{array}$ \\
\hline 1 & $\begin{array}{l}\text { I am able determine whether the content of political information on social } \\
\text { media is moral or immoral. }\end{array}$ & $.929^{* * *}$ \\
2 & $\begin{array}{l}\text { I am able to compare political information from one source to another on } \\
\text { social media. }\end{array}$ & $.974^{* * *}$ \\
3 & $\begin{array}{l}\text { I am able to compare information on social media with my own political } \\
\text { understanding. }\end{array}$ & $.963^{* * *}$ \\
4 & $\begin{array}{l}\text { I consider using social media with high volume of likes, comments, shares. } \\
5\end{array} \quad \begin{array}{l}\text { I am able to make decisions on the validity and accuracy of political } \\
\text { information on social media. }\end{array}$ \\
6 & $\begin{array}{l}\text { I was able to analyze the negative effects (fraud, slander, seduction) of using } \\
\text { political information sources on social media. }\end{array}$ & $.862^{* * *}$ \\
7 & $\begin{array}{l}\text { I am able to evaluate social media that is ethical, moral and integrative in } \\
\text { disseminating political information. }\end{array}$ & $.822^{* * * *}$ \\
\hline
\end{tabular}


INTERNATIONAL JOURNAL OF ACADEMIC RESEARCH IN BUSINESS AND SOCIAL SCIENCES Vol. 10, No. 3, March, 2020, E-ISSN: 2222-6990 @ 2020 HRMARS

\section{Act}

\begin{tabular}{llc}
\hline No & Item & $\begin{array}{c}\text { Statistic } \\
\text { Loading }\end{array}$ \\
\hline 1 & $\begin{array}{l}\text { I am upload authentic political information / news / articles to share with } \\
\text { netizens. }\end{array}$ & $.945^{* * *}$ \\
2 & $\begin{array}{l}\text { I will respond positively to negative comments / comments on political } \\
\text { issues on social media. }\end{array}$ & $.978^{* * *}$ \\
3 & $\begin{array}{l}\text { I do not share, comment or like to immoral, unethical, and politically } \\
\text { incorrect information shared by other social media users. }\end{array}$ \\
4 & I am able to interact with other social media users to discuss political issues. \\
5 & I am joining an entry discussing political issues or scandals on social media. \\
6 & I will report misconduct on social media to the authorities (MCMC and \\
& PDRM). & $.846^{* * *}$ \\
&
\end{tabular}

